\title{
PROTECTION OF NAMES OF AGRICULTURAL PRODUCTS AND FOODS - MARKINGS OF INDICATIONS OF GEOGRAPHIC ORIGIN AND GUARANTEED TRADITIONAL SPECIALTIES
}

\author{
Mario Lukinović343 \\ Zoran Dragojevićc 344 \\ Larisa Jovanović ${ }^{345}$
}

https://doi.org/10.31410/itema.2018.1017

\begin{abstract}
This paper analyzes the protection of names of agricultural products and food - with special reference to the Traditional specialities guaranteed. In the Republic of Serbia, there is no legal basis for registering products with a guaranteed traditional specialty. In the process of harmonization of legal regulations with EU regulations, the Republic of Serbia will also have to adopt this category of products. Although Traditional specialities guaranteed (TSG) did not fully justify expectations in the EU, we believe that their acceptance into our legal system would be positive. Their registration would standardize the process of production of such products and thereby stabilize their quality. These products will have to be subject to continuous quality control and certification of the production process, which unfortunately is not the case at the moment. Also, in this way, the production of agricultural and food products that do not meet the requirements for the protection of geographical indications of origin, whose reputation contributes significantly to the cultural and historical preservation of the identity of certain regions in Serbia, will be further preserved and raised to a higher level. The guaranteed traditional specialties will receive full material affirmation through a tourist offer where the price of these products is several times higher than the market value.
\end{abstract}

Keywords: agricultural products, traditional specialties, indications of geographical origin, protection, value-added products.

\section{INTRODUCTION}

I $\mathrm{n}$ order to differentiate from competition, manufacturers mark their products with different labels that provide consumers with relevant information: on the origin of goods, safety and product quality, the manufacturer, the impact on human health and the environment, and others [2], [8].

In a significant number of works and research, it has been shown that most consumers prefer a large number of nutritional information on the product packaging. However, most consumers do not have the time to concentrate on nutrition information about the product when purchasing consumer goods, making decisions semi-intuitive, guiding them with basic information provided by the product, which are different types of labels that can guide them about product quality. Consumers decide to buy with a lack of attention to the lack of spare time and in the conditions of great offer (usually in super or hypermarkets) that further blur the perception of

\footnotetext{
${ }^{343}$ Faculty of Law, Union University, Belgrade, Serbia

${ }^{344}$ Intellectual Property Office of Serbia, Serbia

${ }^{345}$ University Alfa, Belgrade, Serbia
} 
products. In their choice they rely on the information offered on the products [3]. Although trademarks still have an absolute dominant role in deciding how to give confidence to a product, consumers are increasingly seeking quality assurance through information they receive through additional product labels (certificates, statements, geographical indication, etc.).

The average consumer is not sufficiently versed in the product names (he knows local or those coming from other countries, who have long been used in the market to become generic names for a particular type or type of product), so the EU has introduced PDO tags for its unique economic space for protected designation of origin, PGI for protected geographical indication and TSG for guaranteed traditional specialty.

Qualitative research on attitudes on labels on food, conducted in 2011 and 2013 [7], showed that consumers in Serbia see labels on food products as a form of advertising and advertising, and therefore do not have enough confidence. Insufficient compliance with EU legislation, as well as the lack of effective control over the use of producer statements on products, led to customer skepticism. Using without scientific and research evidence of these effects make this skepticism justified [7].

The demand for specific regional products with a special quality is constantly increasing. Modern forms of transport reduce distance, making these products more accessible. Consumers trust them, because the development of many geographical indications of origin has required a decade's period, and some have passed centuries.

Consumer interests in terms of health and healthcare become an increasingly important factor in consumer decision-making when selecting a product, and the labels on them not only point to the existence of food-health and health links. Food labels, as part of the labeling of products, are increasingly used in the function of differentiating and positioning products [2], [4].

In order to protect and promote traditional and regional agricultural and food products, the European Commission has adopted a number of regulations [5].

Until the adoption of EU regulation no. 510/2006 on the protection of geographical indications and designations of origin for agricultural products and foodstuffs in force was Regulation no. 2081/92, as amended by Regulation no. 535/97.

In the international law only The Lisbon Agreement for the Protection of Appellations of Origin and their International Registration and Regulation no. 510/2006 contain the definition of the Appellation of Origin. The Lisbon Agreement conceptually relies on the traditional understanding of geographical indications in French law. International rules on geographical indications have in substance gone significantly beyond the basic intellectual property/consumer protection rationale [1].

\section{GEOGRAPHICAL INDICATIONS OF ORIGIN}

The roots of legal protection of geographical indications of origin are found in French law, where King Charles IV granted the royal privilege to producers of cheese Roquefort in 1407. Parliament in Toulouse in 1666 proclaimed an act on state rules for the protection of this cheese, which began the development of legal rules for the protection of geographical indications, which reached its peak with a ruling prohibiting the false use of Champagne or sparkling wines [11]. 
Geographical indications of origin for consumers represent a guarantee of constant quality and distinction of origin, or product manufacturer. They provide legal protection against misuse and infringement of the reputation of the original product.

The demand for specific regional products with a special quality is constantly increasing. Modern forms of transport facilitate the marketing of these products making them more accessible.

On the territory of the Republic of Serbia until 1981, the geographical indications enjoyed legal protection based on provisions on unfair competition. Although the law from 1981, the substance of geographical indications was not precisely defined in terms of terminology, it is particularly important because our legislation introduces the appellation of origin as a unique geographical indication for the first time.

The Paris Convention for the Protection of Industrial Property is considered to be the first multilateral agreement concerning the protection of the indications of geographical origin. Although it has the widest scope of application, this convention provides the lowest level of protection for geographical indications of origin, and this was the reason for the adoption of the Madrid Agreement and the Lisbon Arrangement. The Madrid Agreement provided only a higher degree of protection in certain segments, which is one of the main reasons for a small number of members joining it (to date it has been signed by 35 countries).

The Lisbon Agreement for the Protection of Appellations of Origin and their International Registration has enabled the establishment of a system of designations of geographical origin. The International System of Protection of Geographical Indications has been established by the General Agreement on Tariffs and Trade (GATT), which is regulated by the World Trade Organization (WTO). Products protected by the name of origin through the Lisbon Agreement can be protected in 26 countries, of which eight are members of the European Union.

The regulation relating to products with protected geographical origin within the General Agreement is more closely described by the Agreement on the Aspects of the Trade in Intellectual Property Rights (TRIPS). In TRIPs Agreement, geographical indications of origin are explicitly protected in Articles 22 through 24, Section 3 [9].

Regulations No. 509/06 and 510/06, as well as Regulations No. 1898/06 and 1216/07, which set out the rules for the implementation of Regulations (EC) no. 509/06 and 510/06, the European Union also allowed farmers from countries outside the EU to initiate a procedure for the protection of their products with its authorities. This gives the opportunity to gain rights and label products with geographical origin, thus opening the door to the market with hundreds of millions of consumers. Regulation no. 510/2006 geographical designation is conceived in accordance with the TRIPS agreement, while the designations of the name of the origin are arranged in accordance with the Lisbon agreement. The TRIPS agreement introduced a new category of geographical indication for products where there is a link between products and sites on which it is produced, but this link is "weaker" and can be based on the subjective reputation of the product due to its geographical origin.

The terms "indication of source" and "indication of origin" in accordance with the Madrid Agreement for the Repression of False or Deceptive Indications of Source on Goods may be defined as a country code or place in it, as the country or place of origin of the product, and 
accordingly it is customary to translate those terms as "geographical indication", and this term is accepted in legislation and professional literature.

In the Republic of Serbia, the legislator has terminologically defined terms from the Lisbon and Madrid Agreement, and uses the term "geographical indication" as a collective term for the appellations of origin and geographical indication. All designations of origin are at the same time geographical designations of origin, but not all geographical indications of origin are simultaneously a designation of origin. The Law on Indications of Geographical Origin regulate that they are used for the labeling of natural, agricultural, food and industrial products, domestic products and services.

Council Regulation (EC) No 510/2006 of 20 March 2006 regulates the protection of geographical indications and designations of origin for agricultural products and foodstuffs (until the adoption of this Regulation, Regulation no. 2081/92, as amended by Regulation no. 535/97).

\section{STANDARDS AND SPECIAL QUALITY LABELS FOR AGRICULTURAL PRODUCTS}

In order to provide assistance to producers of traditional products in promoting specific (additional) value of their products, Regulation (EU) No. 1151/2012 of the European Parliament and of the Council on quality schemes for agricultural products and foodstuffs (OJ L 343, 14.12.2012) (hereinafter: Regulation (EU) No. 1151/2012), the conditions of use of the symbol of quality are prescribed Guaranteed traditional specialty - GTS (TSG - Traditional specialties guaranteed). The Regulation issue rules that the markings provided for in the schemes of quality of labels and signs do not call into question the rules of the European Union or the Member States that govern intellectual property, in particular those rules relating to geographical indications, appellation of origin and trademarks, and rights granted under those rules.

The indication "traditional" in the sense of "Regulation" means proven use on the domestic market over a period of time that allows transmission from one generation to the next for a period of at least 30 years. " While "marking" refers to "every word, detail, trademark, trade mark, image or sign referring to a foodstuff and which is contained on any package, documentation, notification and label in a relationship with to such food product". The name "registered", as a guaranteed traditional specialty, can be used by every undertaking that places a product on the market that complies with the relevant specification.

The regulation provides for the possibility of using the label "guaranteed traditional specialties" by all interested producers who comply with the appropriate production specification and provided the production is systematically controlled.

Product marked with a quality symbol GTS / TSG is an agricultural or food product manufactured in a traditional manner, that is, from traditional raw materials, which are recognized in accordance with the law, with special properties. This label is primarily protected by a recipe or a method of production; such products are made by those who hold prescribed prescriptions, procedures or methods. For the registration of a GTS / TSG product name, a name that is traditionally used to designate a specific product may be used or describes the traditional or specific properties of a product. Traditional use shall mean proven use for a period of at least 30 years [12]. 
According to Regulation (EU) no. 1151/2012 associations play a key role in the process of applying for registration of the name of the origin, geographical indications and guaranteed traditional specialties, as well as in the change of specifications or requests for cancellation. Associations may develop activities related to the supervision of the implementation of protection of registered names, product conformity with the product specification, information and advertising, or any activity aimed at improving the value of the registered name. The regulation also recommends monitoring the position of products on the market by the association.

Although the scope of protection guaranteed by traditional specialties is improved by this Regulation, it does not explicitly prohibit the use of a translation of the name protected as a traditional specialty guaranteed or its use with the terms "type, type, mode, procedure, imitation". This may result in a loss of consumer confidence in the original product, as unauthorized users using the expression e.g. "Prašská šunka ham" or "Serrano Ham" violet the idea of the quality guaranteed by the traditional specialty enjoyed by consumers (because such products are usually of lower quality than the original ones) [12].

\section{REPUBLIC OF CROATIA}

In the Republic of Croatia, the procedure for registering agricultural and food products begins to be carried out in the 1990s. Since 2003, the process of registration of indications of geographical origin and guaranteed traditional specialties has been transferred to the competence of the Ministry of Agriculture. At that time, a system of registration and protection of the name of agricultural and food products of geographical indications and guaranteed traditional specialties is established, and the harmonization of regulations with the regulations of the European Union begins [10].

The term guaranteed traditional specialty (,zajamčeno tradicionalni specijalitet”) is used ZTS. The area of protection of traditional specialties guaranteed in Croatia is regulated by the Law on Agriculture (NN 30/15) together with indications of geographical origin. Previously, this area was similarly regulated by the Law on Protected Designation of Origin, Protected Geographical Indications and Guaranteed Traditional Specialties Agricultural and Food Products (N N 80/13, 14/14, 30/15), Regulations on Protected Designation of Origin, Protected Geographical Indications and Guaranteed Traditional Specialties Agricultural and Food Products (NN 80/13, 14/14, 30/15). In accordance with the Regulation (EU) no. 1151/2012 and Commission Implementing Regulation (EU) No 668/2014 of 13 June 2014 laying down rules for the application of Regulation (EU) No 1151/2012 of the European Parliament and of the Council on quality schemes for agricultural products and foodstuffs.

The national procedure for the protection of the name of agricultural and food products of indications of geographical origin and guaranteed traditional specialties is defined by the Regulation amending the Regulation on protected designations of origin, protected geographical indications and traditional specialties guaranteed for agricultural products and foodstuffs (NN 65/15). The Rules also prescribe the conditions for obtaining, appearance and use of registered marks.

\section{REPUBLIC OF MONTENEGRO}

As in Croatia, this area in Montenegro is regulated by a single law, by the Law on Designations of Origin, Geographical Indications and Designations of Guaranteed Traditional Specialty Agricultural Products and Foodstuffs (Official Gazette of Montenegro, No. 18/11). The law 
regulate the special features necessary to possess a product: a characteristic or a set of characteristics that clearly distinguish an agricultural or food product from similar agricultural or food products of the same category, which may relate to specific product characteristics such as physical, chemical, microbiological or organoleptic, the characteristics of the product or the production method used by the manufacturer or on special conditions during its production [6].

In Montenegro, the register of names of traditional specialties guaranteed is managed by a line ministry. The register contains two lists of guaranteed traditional specialties, depending on whether the use of the name of an agricultural or food product is reserved for producers who meet the requirements of the product specification. The term "guaranteed traditional specialties", which is registered without reservation of the name, can only be used to identify agricultural or food products produced in accordance with the specification, as a traditional specialty guaranteed.

For producers who use the label "guaranteed traditional specialty" for a product that does not meet the requirements of the specification guaranteed traditional specialties or are not registered in the Register of beneficiaries of this names, the Law issue misdemeanor fines for violation in the amount of 500 to 10.000 Euros.

The existing system gives the possibility to register a name for identification without retaining the names in the European Union. Since interested parties did not understand this possibility sufficiently well, and the role of identifying traditional products can be better achieved at the level of a Member State or region, applying the principle of subsidiarity, this option should be abolished. In terms of experience, the system should only be eligible for names across the European Union.

In order to preserve the link between the quality of products and the environment in which the originating products arise, greater investment and state support are needed. Higher investments will additionally contribute to the preservation of history, culture and respect for tradition in the production and processing of certain products, and therefore local communities involved in this production. Potential of originating products could also have a wider social significance, primarily in preserving autochthonous plant varieties and animal species, as well as in promoting the protection of local resources and preserving the environment [13].

\section{CONCLUSION}

Since the adoption of Regulation 2082/92 EEC, through Regulation 509/2016 to Regulation $1151 / 2012$, which is now in force, 58 products have been registered as guaranteed traditional specialties (TSGs). In the same period, Regulations 2081/92, 510/2006 and 1151/2012 registered 635 names of origin (PDOs) and 739 geographical indications (PGIs). The total for all three categories of protected products is 1,432 products. In the total mass of protected products, guaranteed traditional specialties make up only $3.78 \%$ of registered products.

The above figures (indicators) speak for themselves. Producers of agricultural and food products, by rules, avoid to protect their products with guaranteed traditional specialties and in every possible way try to protect them with their geographical indications. The Stresa Convention (International Convention for the Use of Appellations of Origin and Denominations of Cheesesis) from 1951 is a classic example of this. Namely, only four cheeses: Gorgonzola, Parmigiano Reggiano, Pecorino Romano and Roquefort have fulfilled the conditions for production in a certain place of origin, what we would call today the name of origin, PDO. 
Other cheeses could be subdued under what we now call guaranteed by a traditional specialty, TSG, because the process of production or recipes was important to them. On the list of these cheeses were found Danish Danablu and Esrom, Italian Asiago, Fiore Sardo and Fontina and Swedish Svecia. The Italians protected their cheeses Asiago and Fontina with the name of their origin through the Lisbon Treaty, in the first year of 2014 and the second in 1969, and the same year at the European Union level. The Danes protected their cheeses Danubel and Esrom as geographical indications, PGI, and at the level of the EU the same thing was done by Sweden with its cheese Svecia.

Producers protect products guaranteed by traditional specialties almost only in case the product name has become generic, for example, Pražská ham or Mozzarella, both in the domestic market (in the country of origin) and outside (common EU market), or when it cannot be protected with the geographical indication, because natural factors are lacking to give specific properties and quality to a product such as, for example, with Pizza Napoletana. Products that are guaranteed by traditional specialties, TSG, have their own logos under which they are placed on the market. These are usually collective trademarks, associations of producers and other entities that are linked by the process of production or distribution of these products. Unlike indications of geographical origin, guaranteed traditional specialties are not subject to strict restrictions such as the transfer of rights, licenses, pledges or franchises.

In the Republic of Serbia, there is no legal basis for registering products with a guaranteed traditional specialty. In the process of harmonization of legal regulations with EU regulations, the Republic of Serbia will have to introduce this category of products. Until it becomes a full member of the EU, Serbia will not be able to use the TSG mark on its products reserved for EU Member States. In the transitional period until full EU membership in the Republic of Serbia, a national mark for this type of product will be used.

The guaranteed traditional specialties (TSGs) did not fully meet the expectations in the EU, as can be seen from the number of registered products with this label. It is expected that a similar situation will be in the Republic of Serbia. However, we consider that their introduction into the legal system of the Republic of Serbia would be positive for several reasons. Their registration would standardize the process of production of such products and thereby stabilize their quality. These products will have to be subject to continuous quality control and certification of the production process, which unfortunately is not the case now. Also, in this way, the production of agricultural and food products that do not meet the requirements for the protection of indications of geographical origin, whose reputation contributes significantly to the cultural and historical preservation of the identity of certain regions in Serbia, will be further preserved and raised to a higher level.

The production of value-added products as guaranteed and guaranteed by traditional specialties in the Republic of Serbia is not large. The guaranteed traditional specialties will receive full material affirmation through a tourist offer where the price of these products is several times higher than the market value.

\section{REFERENCES}

[1] Broude T. (2014). Taking "Trade and Culture" Seriously: Geographical Indications and cultural protection in WTO Law, Penn Law: Legal Scholarship Repository.

[2] Čajka Z., Jovanović L. (2016). Dizajn i ambalaža ekološkog proizvoda, Ecologica 84, 768773. 
[3] Čajka Z., Jovanović L., Radosavljević M. (2017). Potrošači i procesi kupovine održivih proizvoda, Ecologica 86, 305-310.

[4] Jovanović L., Plećaš M. (2014). Implementacija standarda kvaliteta i bezbednosti u prehrambenoj industriji Srbije, Ecologica 76, 811-816.

[5] Lovre, K. Kresoja, M. (2014). Ekonomski odrazi neoliberalne politike cena poljoprivredno-prehrambenih proizvoda u Srbiji, Marketing prehrambenih proizvoda, Dosije studio.

[6] Law on Designations of Origin, Geographical Indications and Designations of Guaranteed Traditional Specialty Agricultural Products and Foodstuffs ("S. 1. CG", br. 18/2011).

[7] Mitić, S. Gligorijević, M. (2014). Kvalitativno istraživanje stavova potrošača o oznakama na hrani, Marketing prehrambenih proizvoda, Dosije studio.

[8] Ognjanov, G. Stojanović, Ž. Veljković, S. (2014). Percepcija i stavovi potrošača u Srbiji u pogledu oznaka o poštovanju dobrobiti farmskih životinja, Marketing prehrambenih proizvoda, Dosije studio.

[9] Panizzon, M. (2006). Traditional Knowledge and Geographical Indications: Foundations, Interests and Negotiating Positions, NCCR Trade Regulation Working Paper No. 2005/01, Developing Countries in the Doha Round: WTO Decision-Making Procedures and WTO Negotiations on Trade in Agricultural Goods and Services, Ernst-Ulrich Petersmann, ed., Robert Schuman Centre for Advanced Studies, European University Institute.

[10] Sinković, K. (2017). Sustavi kvalitete za poljoprivredne i prehrambene proizvode, Sheme kvaliteta hrane zaštićene oznakama izvornosti, zaštićenim oznakama zemljopisnog podrijetla i zajamčeno tradicionalnim specijalitetima poljoprivrednih i prehrambenih proizvoda, Zagreb.

[11] Spasojević, S. (2013). Kolizija geografskih oznaka i žigova (doktorska disertacija), Pravni fakultet Univerziteta u Kragujevcu, Kragujevac.

[12] Volar Pantić, E. (2014). Propisi za sheme kvalitete poljoprivrednih i prehrambenih proizvoda, PLAC Projekat, Beograd.

[13] Vandecandelaere E. Arfini F. Belletti G. Marescotti A. (2010). Linking: people, places, products A guide for promoting quality linked to geographical origin and sustainable geographical indications, FAO. 